\title{
THE COMPARISON BETWEEN STRUCTURAL PARTICLE “地” IN MANDARIN AND STRUCTURAL PARTICLE "DENGAN" ATAU "SECARA" IN INDONESIAN
}

\author{
Elvira Septevany ${ }^{1}$, Liu Dandan ${ }^{2}$, Qin Weifen ${ }^{3}$, Lu Xing $^{4}$ \\ ${ }^{I}$ Tourism Department, Politeknik Negeri Bali \\ ${ }^{2}$ International Cooperation Exchange Center, Nanchang Normal University, China \\ ${ }^{3}$ School of Foreign Languages, Hefei University of Technology, China \\ ${ }^{4}$ Study Program of Linguistik, Program Doktor, Universitas Udayana
}

\begin{tabular}{l}
\hline ARTICLE INFO \\
\hline Received:2021-01-21 \\
Accepted: 2021-03-21 \\
Published: 2021-03-22 \\
Volume: 5 \\
Issue: 1 \\
DOI: \\
https://doi.org/10.33019/lire.v \\
3i2.105 \\
\hline KEYWORDS
\end{tabular}

Structural particle "secara" atau "dengan", structural particle “地”, differences, simmilarities

ABSTRACT

The uses of structural particle "地 dengan/secara" in Mandarin or in Indonesian ha ve similarities and differences. In order to compare these two words, the writer uses contrastive analysis which is a study to identify the differences and similarities between Indonesian and Mandarin structural particle. The data collection technique was done by using purposive sampling technique. It was taken randomly from Modern Indonesian books and then compared with structural particle in Mandarin. The result of this analysis is that there are similarities and differences in the use of the structural particle "地 de" in Mandarin and "dengan" or "secara" in Indonesian. Besides, there are also differences in word usage. The difference can be seen from the uses of structural particle "地 de" in Mandarin and the structural particle "dengan" or "secara" in Indonesian in other words. The “地” marker in Mandarin can only corresponds to the a djective word class while the Indonesian la nguage is more flexible because the structural particle "dengan" or "secara" can match the adjective, verb, noun, or adverb word class. The structural particle "dengan" or "secara" when corresponding to the word class will indica te a method, style or manner of doing something.

\section{INTRODUCTION}

Nowadays, more and more people are dedicating time to study Mandarin as a second language. Mandarin and Indonesian come from different language families, however, these two languages still have some similarities. For example, "dengan" or "secara" in Indonesian and "地 de" in Mandarin are structural particle as a marker. In Indonesian or Mandarin, the structural particle “地 dengan or secara” is an adverbial marker. The Mandarin “地 de” and Indonesian “dengan” or "secara" in usage are same, all of them describe the uses of action or actual structural particle. This structural particle is used to modify or to limit adjectives or verbs. So, the structural adjective “地 de" is placed in front of an adjective or verb (Wang Di, 2010). According to Yan Ling (2019), the use of the word “地 de" is very complicated because there are some words require the structural

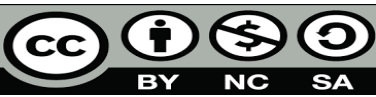


particle “地 de”, there are some words don't require it and some are just optional. The structural particle “地 de” can turn an adjective into an adverb. In general, the adjective “单音节” doesn't need the addition of “地 de".

According to Lie Zheng Lian, the structural particle “地 de” in Mandarin is also divided into three, namely “的, 地, 得”. The usage of the structural particle “的, 地, 得” is different. The structural particle “的 de” is placed in front of a noun, the structural particle “地 de" is placed in front of the verb, and the structural particle “得 de” is placed in front of complement (Liu Zheng Lian, 1994). Apart from the different placement of structural particle “地 de”, this difference also causes mistakes for foreign students who are learning about this. Angela conducted a research on the analysis of structural auxiliary words “的, 地, 得” in students of class 2017. According to Angela (2018), there were many errors in the uses of the three structural particle “的, 地, and 地”. The most common error was the addition error or omission error of the structural particle “的 de”. Liu Xue Mei (2006) wrote about the misuses of the word "de" in sentences.

There were 4 types of usage errors, namely “地 de” misuse with the word “的 de”, “的 de” misuse with the word “地 de”, “得 de” misuse with the word “的 de”, and the last one was “ 的 de” misuse with the word “得 de”. There were about 576 sentences with the word “地, 的, 得 de”. From these sentences, about $436(87.6 \%)$ was “地 de” misuse with the word “的 de”, then about $31(6.22 \%)$ was “得 de” misuse with the word “的 de”, then about $21(4.22 \%)$ was “的 de” misuse with the word “地 de”, and about $10(2.01 \%)$ was “的 de” misuse with the word “得 de”. The errors of foreign students in learning about the uses of the word “的, 地, 得” have a high error rate. Wan Yi (2019) suggests that this error rate can be lowered, namely by providing more practice and also updating the textbook used as a guide in learning the structural particle “的, 地, 得 de”. These differences and mistakes make the writer want to compare the uses of structural particle “dengan" or "secara” in Indonesian and “地 de" in Mandarin. This research is very important to do because the Indonesian students can understand the rules for using structural particle “地 de”. 
It is used in writing and daily conversation in Mandarin. Besides, the main reason the writer wants to do this research is because the example research is taken from Modern Indonesian books who written by a Mandarin native speaker. This research also has never been done by previous researchers.

\section{METHODOLOGY}

The method used by the author is contrastive analysis, which is a systematic study of language pair to identify differences and similarities between them (Brown, 1973). The author also uses contrastive analysis to analyze the Comparison of Mandarin Aspects and Indonesian Aspects which is never discuss it before (Elvira, 2018). Through this contrastive analysis, the author looks for differences and similarities between the structural particle "dengan" or "secara" in Indonesian and the structural particle “地 de" in Mandarin. The data collection technique was done by using purposive sampling technique, which is a technique of taking data samples with certain considerations (Sugiyono 2010: 128).

The sample used is an example of a structural particle "dengan" or "secara" in Modern Indonesian book that written in Mandarin by a Mandarin native speaker (Yu, 1993). Data was taken randomly from this book and compared with structural particle in Mandarin. After the data was collected, the authors analyzed it by comparing the use of particle “地” with "dengan" or "secara" based on the guidelines by rules for using the structural particle “地”. The purpose of this descriptive study is to make descriptions systematically as well as the relationship between the phenomena being investigated, particularly the relationship between the structural particle “地” in Mandarin and the structural particle "dengan" or "secara" in Indonesian.

\section{RESULTS AND DISCUSSION}

Mandarin and Indonesian have structural particle “地 de" and "dengan" or "secara" as a markers.

Below are several word classes that can be match with structural particle "地 de" in Mandarin and "dengan" or "secara" in Indonesian. 


\section{a. Structural particle “地 de" and “dengan” or "secara” + “副词 fuci” adverb "segera”}

In Indonesian, only the structural particle "dengan" can match with adverb "immediately", while the structural particle "secara" cannot match with adverb "segera". Example:

dāng tā tīngdào nàgè huài xiāoxī măshànghuíjiā

当他听到那个坏消息, 马上回家。Dia dengan segera pulang ke rumah saat mendengar kabar buruk itu.

\begin{tabular}{|c|c|c|c|c|c|c|c|c|}
\hline Dia & dengan & segera & $\begin{array}{c}\text { pulang ke } \\
\text { rumah }\end{array}$ & saat & mendengar & kabar & buruk & itu. \\
\hline 他 & & 马上 & 回家 & 当 & 听到 & 消息 & 不好 & 那 \\
\hline $\mathrm{He}$ & immes & liately & returned home & when & heard & news & bad & that \\
\hline
\end{tabular}

In Indonesian, the structural particle "dengan" can be optional when it matches with adverb "segera" because it does not act as a marker for the adverb, but only as an adverb auxiliary to further emphasize the meaning of the adverb. In Mandarin “副词 Fuci” means adverb. The structural particle “地 de” cannot be used as a marker for the adverb “马上 dengan segera” because it acts on its own as a function of the adverb.

\section{b. Structural particle “地 de" and “dengan" or "secara" + 形容词 adjective}

In Indonesian and Mandarin, the structural particle "dengan" or "secara" and “地 de" are mostly match with "adjectives". The structural particle "dengan" or "secara" must be placed before the "adjective" to describe the process or to tell us how something is done, when it is done, and where it is done. Example:

hăizéi gāoxìng de huídào tāmen de sīlìngbù

海 贼 高兴地回到他们的司令部。Bajak laut dengan gembira pulang ke markasnya.

\begin{tabular}{ccccc}
\hline Bajak laut & Dengan & gembira & pulang ke & Markasnya. \\
\hline 海贼 & 地 & 高兴 & 回到 & 他们的司令部 \\
\hline The pirates & \multicolumn{2}{c}{ happily } & return & to their base. \\
\hline
\end{tabular}


The adverb "happily" shows that the pirate's feeling upon return to his base. The structural particle “地 de" and "dengan" or "secara" above tell us how the pirate's feeling. Another example about marker “地 de" with adjective "mudah" and "simpel”are shown below.

tā qīngsōng de dăbài leduìshǒu

她轻松地打败了对手。Dia dengan mudah telah mengalahkan lawannya.

\begin{tabular}{|c|c|c|c|c|c|}
\hline 她 & 轻松 & 地 & 打败 & 了 & 对手。 \\
\hline Dia & mudah & dengan & mengalahkan & telah & lawan. \\
\hline $\mathrm{He}$ & & & defeatec & & his opponent \\
\hline
\end{tabular}

tā jiăndān de jièshào le yíxià zìj

她简单地介绍了一下自己。Dia secara simpel memperkenalkan dirinya.

\begin{tabular}{|c|c|c|c|c|c|}
\hline 她 & 简单 & 地 & 介绍了 & 一下 & 自己。 \\
\hline Dia & simpel & secar & memperkenalkan & (sedang berlangsung) & diri sendiri. \\
\hline She & & & intr & ducing & herself \\
\hline
\end{tabular}

These examples show that the marker "地” in Mandarin or "secara/dengan" in Indonesia modifies the adjectives "mudah" to show how easily he defeated his opponent and and marker " 简单 simpel” to show how easily he introduces herself. So the marker “地” in Mandarin or "secara/dengan" in Indonesia can be match with adjective “轻松 mudah” and “简单 simpel”. The difference between “地 de” and “dengan/secara” markers is their position in the sentences. In Mandarin, the structural particle “地” comes after the adjective, while in Indonesian, the structural particle "dengan/secara" comes before the adjective.

In addition to adjectives consisting of two syllables, the repeating adjective can also match to the Mandarin structural particle “地” as shown in example below.

tā yí gè rén mòmò de chéngshòu gèzhǒng yālì

他一个人 默默地承受各种压力。Dia seorang diri secara diamdiam memikul berbagai beban/tekanan.

\begin{tabular}{ccccccc}
\hline 她 & 一个人 & 默默 & 地 & 承受 & 各种 & 压力。 \\
\hline Dia & seorang diri & diam-diam & secara & memikul & berbagai & beban/tekanan. \\
\hline $\mathrm{He}$ & himself & secretly & & burden & any & pressure \\
\hline
\end{tabular}


This example shows that “默默 diam-diam” in Mandarin is an adjective and can be paired with structural particle “地”. While in Indonesian "diam-diam” also can be paired with structural particle "secara" to shows he can burden any pressure secretly. In Indonesian, the grammatical function of "diam-diam" is as an adverb (not as an adjective).

\section{c. Structural particle “地 de" and “dengan" or "secara" + 动词 verb}

In Mandarin, the structural particle “地 de” can be modified the word “轻轻松松 qingqingsongsong". The Indonesian structural particle "dengan" also can modified the word "rileks" to shows how they spent their holiday relaxedly. The word “轻轻松松 rileks" is an adjective, but in Indonesia "rileks" is a verb. The difference shows that structural particle "地 de" with "dengan" or "secara" as a marker can be match with the verb "rileks" and adjective “轻轻松松”. The sentence can be seen below.

tāmen qīngqīngsōngsōng de dùguò le yí gè jiàqī

他们 轻 轻松 松 地度过了一个假期。 Mereka dengan rileks melewati sebuah liburan.

\begin{tabular}{ccccccc}
\hline 他们 & 轻轻松松 & 地 & 度过 & 了 & 一个 & 假期。 \\
\hline Mereka & rileks & dengan & melewati & telah & sebuah & liburan. \\
\hline They & Relaxedly & spent & & a & holiday \\
\hline
\end{tabular}

The structural particle “dengan” or “secara” can be omitted if it corresponds to the word “明 明 openly”, but does not lose its meaning. The sentence can be seen below.

tā míngmíng zài hěn duōrén de miànqián mà wǒ

她明明在很多人 的面前骂我。Ia secara terang-terangan memaki saya di depan orang banyak.

\begin{tabular}{|c|c|c|c|c|c|c|c|}
\hline $\mathrm{Ia}$ & secara & terang-terangan & memaki & saya & di depan & orang & banyak. \\
\hline 她 & & 明明 & 骂 & 我 & 在.. 面 & 人 & 多 \\
\hline $\mathrm{He}$ & & Openly & cursed & me & in front of & people & many \\
\hline
\end{tabular}

In Indonesian, the structural particle "secara" can modified the verb "terang-terangan". Whereas in Mandarin, the structural particle “地 de” cannot modified the adverb “明明 mingming” 
because the word “明明 mingming” has already become an adverb. It means structural particle “ 地 de" cannot modified the adverb.

The structural particle “地 de” can matches the word “匀忙 hurry”. Here the word “刎忙 congmang" is an adjective. Meanwhile in Indonesian the word "terburu-buru" is a verb. The difference can be shown below.

tā cōngmáng de huí dào jiā

他勿忙地回到家。Ia dengan terburu-buru pulang ke rumah.

\begin{tabular}{ccccc}
\hline Ia & dengan & terburu-buru & pulangke & rumah \\
\hline 她 & 地 & 勿忙 & 回到 & 家 \\
\hline She & & hurriedly & returned & home \\
\hline
\end{tabular}

\section{d. Structural particle “地 de” and “dengan/secara” + 名词 noun}

In Indonesian, the word "detail" is a noun. The noun "detail" can correspond to the structural particle "dengan” or "secara". Whereas the word “详细 detail” in Mandarin is an adjective. It can correspond to the structural particle “地”. So it can be concluded that the noun in Mandarin cannot match the structural particle "地 de". Meanwhile, the noun in Indonesian can correspond to the structural particle "dengan" or "secara". Example can be seen below.

tā xiángxì de jiăngshù le zhèduàn lìshǐ

他详细（地）讲述了这段历史。Dia secara mendetail telah menjelaskan bagian sejarah ini.

\begin{tabular}{cccccc}
\hline 他 & 详细 & (地) & 讲述了 & 这段 & 历史。 \\
\hline Dia & mendetail & secara & telah menjelaskan & bagian ini & sejarah. \\
\hline $\mathrm{He}$ & detail & In & described & this part & history \\
\hline
\end{tabular}

The noun "detail" is preceded by structural particle "dengan" or "secara" as a marker. In Mandarin, structural particle “地 de" is optional because it has the same meaning. Meanwhile in Indonesian, it is necessary to add structural particle "secara" to change the function of the noun "detail" to be adverb "secara detail". 


\section{e. Discussion}

Similarities between Mandarin and Indonesian in using the structural particle “地 de" and the structural particle "dengan" or "secara" as a marker are shown in Table 1.

Table 1. Similarities in Mandarin and Indonesian

\begin{tabular}{|c|c|c|c|}
\hline No & Structure & Mandarin & Indonesian \\
\hline 1 & $\begin{array}{l}\text { Structural particle “地 de" } \\
\text { and "dengan" or “secara" } \\
\text { + 形容词 adjective. }\end{array}$ & $\begin{array}{l}(\sqrt{ }) \text { 海贼高兴地回到他们 } \\
\text { 的司令部。 } \\
(\sqrt{ }) \text { 她轻松地打败了对 } \\
\text { 手。 } \\
(\sqrt{ }) \text { 她简单地介绍了一 } \\
\text { 下自己。 }\end{array}$ & $\begin{array}{l}\text { ( } \sqrt{ }) \text { Bajak laut dengan } \\
\text { gembira pulang ke } \\
\text { markasnya. } \\
(\sqrt{ }) \text { Dia dengan mudah } \\
\text { mengalahkan lawan. } \\
(\sqrt{ }) \text { Dia secara simpel } \\
\text { memperkenalkan dirinya. }\end{array}$ \\
\hline 2 & $\begin{array}{l}\text { Structural particle “地 de" } \\
\text { and "dengan" or "secara" } \\
+ \\
\text { “轻轻松松 rileks". }\end{array}$ & $\begin{array}{l}(\sqrt{ }) \text { 他们轻轻松松地度 } \\
\text { 了过了一个假期。 }\end{array}$ & $\begin{array}{l}(\sqrt{ }) \text { Mereka dengan } \\
\text { rileks melewati sebuah } \\
\text { liburan. }\end{array}$ \\
\hline 3 & $\begin{array}{l}\text { Structural particle “地 de" } \\
\text { and "dengan" or "secara" } \\
\text { + “默默 diam-diam". }\end{array}$ & $\begin{array}{l}\sqrt{ }) \text { 他一个人默默地承受 } \\
\text { 各种压力。 }\end{array}$ & $\begin{array}{l}(\sqrt{ }) \text { Dia secara diam- } \\
\text { diam memikul berbagai } \\
\text { beban/tekanan. }\end{array}$ \\
\hline 4 & $\begin{array}{l}\text { Structural particle “地 de" } \\
\text { and “dengan" or “secara" } \\
+ \\
\text { “仅忙 terburu-buru”. }\end{array}$ & 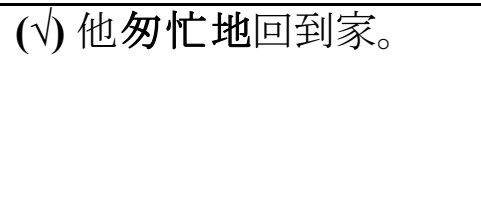 & $\begin{array}{l}(\sqrt{ }) \text { Ia dengan terburu- } \\
\text { buru pulang ke rumah. }\end{array}$ \\
\hline 5 & $\begin{array}{l}\text { Structural particle “地 de” } \\
\text { and “dengan/secara”+“详 } \\
\text { 细 mendetail”. }\end{array}$ & $\begin{array}{l}(\sqrt{ }) \text { 他详细（地）讲述了 } \\
\text { 这段历史。 }\end{array}$ & $\begin{array}{l}(\sqrt{ }) \text { Dia secara } \\
\text { mendetail telah } \\
\text { menjelaskan bagian } \\
\text { sejarah ini. }\end{array}$ \\
\hline
\end{tabular}

As shown in Table 1, there are 5 similarities between the uses of structural particle “地” in Mandarin and the structural particle "dengan" or "secara" in Indonesian. In part 1, there are 3 sentences that have the structural particle "地” and "dengan" or "secara" which can tag adjectives. Part 2 shows that the structural particle “地” and “dengan” or “secara” can mark the word “静静 松松 rileks". Meanwhile part 3 to 5 also show that the structural particle “地” and “dengan” or “secara” all can mark the words “默默 silently, 勿忙 rush, 详细 detail” into adverb functions. 
Differences between Mandarin and Indonesian in using the structural particle “地 de" and the structural particle "dengan" or "secara" as a marker are shown in Table 2.

Table 1. Differences in Mandarin and Indonesian

\begin{tabular}{|c|c|c|c|}
\hline No & Structure & Indonesian & Mandarin \\
\hline 1 & $\begin{array}{l}\text { Structural particle “地 de" and } \\
\text { "dengan" or “secara" + 副词 } \\
\text { adverb "segera". }\end{array}$ & $\begin{array}{l}(\sqrt{ }) \text { Dia dengan } \\
\text { segera pulang ke } \\
\text { rumah saat } \\
\text { mendengar kabar } \\
\text { buruk itu. }\end{array}$ & $\begin{array}{l}\text { (X)当他听到那 } \\
\text { 个坏消息, 马上 } \\
\text { 回家。 }\end{array}$ \\
\hline 2 & $\begin{array}{l}\text { Structural particle “地 de" and } \\
\text { "dengan" or "secara" + 动词 } \\
\text { verb. }\end{array}$ & $\begin{array}{l}(\sqrt{ }) \text { Ia secara } \\
\text { terang-terangan } \\
\text { memaki saya di } \\
\text { depan orang } \\
\text { banyak. }\end{array}$ & $\begin{array}{l}\text { (X) 她明明在很 } \\
\text { 多人面前骂我。 }\end{array}$ \\
\hline 3 & $\begin{array}{l}\text { Structural particle “地 de" and } \\
\text { "dengan" or "secara"+ “默默 } \\
\text { diam-diam". }\end{array}$ & $\begin{array}{l}\text { ( }) \text { Dia secara } \\
\text { diam-diam memikul } \\
\text { berbagai } \\
\text { beban/tekanan. }(\sqrt{ })\end{array}$ & $\begin{array}{l}\text { 他一个人默默地 } \\
\text { 承受各种压力。 }\end{array}$ \\
\hline 4 & $\begin{array}{l}\text { Structural particle “地 de" and } \\
\text { "dengan" or “secara" + “夘忙 } \\
\text { terburu-buru". }\end{array}$ & $\begin{array}{l}(\sqrt{ }) \text { Ia dengan } \\
\text { terburu-buru } \\
\text { pulang ke rumah. }\end{array}$ & 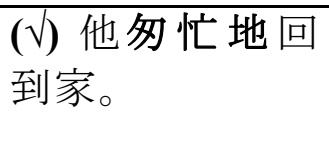 \\
\hline 5 & $\begin{array}{l}\text { Structural particle “地 de" and } \\
\text { "dengan/secara" }+ \text { “详 细 } \\
\text { mendetail". }\end{array}$ & $\begin{array}{l}\sqrt{ }) \text { Dia secara } \\
\text { mendetail telah } \\
\text { menjelaskan bagian } \\
\text { sejarah ini. }\end{array}$ & $\begin{array}{l}\text { ( }) \text { 他详细 } \\
\text { (地) 讲述了这 } \\
\text { 段历史。 }\end{array}$ \\
\hline
\end{tabular}

Table 2 shows that there are 5 differences between the uses of structural particle “地” in Mandarin and "dengan" or "secara" in Indonesian. In part 1 and 2, only in the Indonesian column indicate the uses of structural particle "dengan" or "secara" as adverbial markers. The word "segera" is a class of adverbs and the word "terang-terangan" is a class of verbs. In Indonesian, the verb and adverb can correspond to structural auxiliaries to further strengthen the class position of the adverbial word. Meanwhile in Mandarin, the structural particle "地" cannot match the adverb or verb class because it already has its own word that acts as an adverb word class. Meanwhile part 3 and 4 show the uses of words "默默 diam-diam" and "匀忙 terburu-buru" in Mandarin and 
Indonesian. Both can correspond to the structural particle but there are different classes of words. In part 3, the word "默默" is a class of words from repeated adjectives, while "diam-diam" in Indonesian is a class of words from adverbs. Likewise in part 4, "勿忙" is a class of words from adjectives, while "terburu-buru" is a class of words from verbs. The last section shows that the two markers can correspond to the word “详细 detail”, but also come from different classes. The Table 2 shows that the structural particle “地” as a marker in Mandarin can only correspond to the adjective word class, while Indonesian is more flexible because the "dengan" or "secara" as a marker can correspond to the adjective, verb, noun, or adverb word class. The structural particle "dengan" or "secara" as a marker when corresponding to the word class will indicate method, style or manner of doing something.

\section{CONCLUSION}

In Indonesian and Mandarin, the structural particle “地 de" and "dengan" or "secara" are placed after the adjective. However, the structural particle “地 de" in Mandarin and the structural particle "dengan" or "secara" in Indonesian have some similarities and differences. The similarities are shown by the uses of adjective word class which can match with the structural particles in Mandarin and Indonesian. The differences are shown by the uses of some word class like adverb, verb and noun with structural particle. In Mandarin, the word class adverb, verb or noun cannot be added to the structural particle to convert it into adverbial markers because the words that already become adverbial. Unlike the Indonesian word class like adverb, verb and noun can correspond to the structural particle "dengan" or "secara" as adverbial markers because it strengthens the meaning of the sentence.

\section{Acknowlegments}

The author thanks the editors and reviewers of the journal LIRE who have helped to improve this research. 


\section{REFERENCES}

[1] Ling, Y. (2019). 基于 “HSK 动态作文语料库”的结构助词“地”的偏误分析 Analisis kesalahan Auxiliary structural "dengan/secara" berdasarkan pada "HSK Dnyamic composition Corpus". Shanxi Youth Journal, (127).

[2] Di, W. (2010). 浅谈结构助词“的、地、得”用法。Tentang penggunaan kata-kata tambahan struktural 'de, de, de”. Hanyu Zhishi Journal, 08(22).

[3] Mei, L. X. (2006). 结构助词“的、地、得”用法分析。Analisis penggunaan kata bantu “de”. Xiandai Yu Wen Journal, 12(98-99).

[4] Lian, L. Z. (1994). 再谈“的、地、得”的用法 Penggunaan kata bantu “de, de, de”. Xinwen Sanwei, 06, 35.

[5] Yi, W. (2019). 浅论对外汉语结构助词“的, 地, 得”的教学. Course Education Research, 11(66).

[6] Yu, Z., Q. (1993). 现代印尼语 Bahasa Indonesia Modern. China: 外语教学语研究出版社 Foreign Language Teaching Language Research.

[7] Angela, S., Markali, A. G., Chun-I, K.(2018). Analisis kesalahan penggunaan kata bantu struktural “的, 地, 得”, pada mahasiswa angkatan 2017.Century, 5(1-11). DOI: 10.9744/century.6.2.1-11

[8] Sugiyono. (2010). Metode Penelitian Pendidikan (Pendekatan kuantitatif, Kualitatif dan R \& D). Bandung: Alfabeta, 128.

[9] Brown, R. (1973). A First Language: The Early Stages. Cambridge, Mass.: Harvard University Press.

[10] Septevany, E. (2018). The comparison of Mandarin aspects and Indonesian aspects. ELS Journal on Interdisciplinary Studies on Humanities, 1(3), 366-374. 